\title{
Serving the Individual Traveler: "Biki" Oberoi
}

\section{By focusing on the individual business traveler, "Biki" Oberoi has guided Oberoi Hotels from their base in India to management of 31 hotels in nine countries on four continents}

\section{by Chekitan S. Dev and Al Glanzberg}

AS CHIEF of Oberoi Hotels, Prithviraj S. Oberoi has one of the most difficult jobs a person could ask for. He runs the hotel chain started by his father, Mohan S. Oberoi. In 1934, when hotel keeping in India was in its infancy, M. S. Oberoi became the first Indian national to enter the hotel field by acquiring Clarkes Hotel in Simla. Previously, hotels in India were owned by British and Swiss families and catered mainly to British residents. M.S. Oberoi expanded his group of hotels, and in 1965, he introduced the first

Chekitan S. Dev, Ph.D., an assistant professor of marketing at Cornell University School of Hotel Administration, is a native of India and a graduate of the Oberoi School of Hotel Management. Al Glanzberg, who specializes in writing about international travel, spent a month in India researching the Oberoi organization.

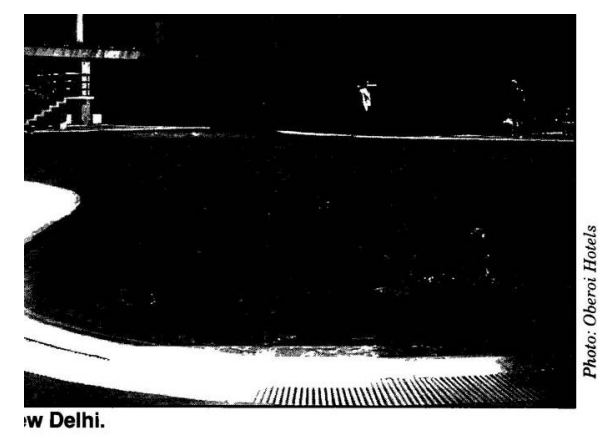

The Oberoi Hotel in New Delhi. 


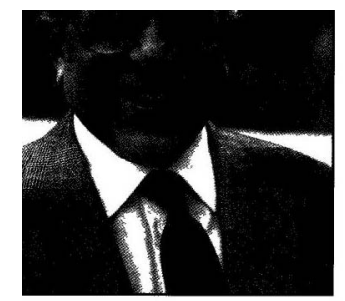

Oberoi: "Motivation is the key cessful hotel operation. To ite people, you must listen to oncerns, and you must tell Ionestly what they can expect t company."

i

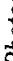

nia, Indonesia, Australi In addition to the hotels Hotels has a substantia catering business, opera restaurants, has an exp export company, and ru India's largest travel ag Mercury Travels. Here i the Oberoi hotel chain a

Oberoi's Global Stra The Oberoi group aims 1 international and dome: traveler. Oberoi seeks tc high degree of personali and a high standard of 1 comfort. The city hotels cater to upscale traveler business executives on $\epsilon$ accounts. Personalized s stressed so much that it employ an average of th per room.

"Biki" Oberoi: "Motivation is the key to successful hotel operation. To motivate people, you must listen to their concerns, and you must tell them honestly what they can expect in your company." five-star deluxe hotel in India - the Oberoi Inter-Continental in New Delhi. He also began international expansion in the '60s, opening the Soaltee Oberoi in Kathmandu and managing the historic Mena House hotel in Cairo.

Today, Oberoi operates hotels in India, Nepal, Sri Lanka, Singapore, Egypt, Saudi Arabia, Tanzania, Indonesia, Australia, and Iraq. In addition to the hotels, Oberoi Hotels has a substantial in-flight catering business, operates airport restaurants, has an expanding export company, and runs one of India's largest travel agencies, Mercury Travels. Here is a look at the Oberoi hotel chain and family.

\section{Oberoi's Global Strategy}

The Oberoi group aims to serve the international and domestic affluent traveler. Oberoi seeks to give a high degree of personalized service and a high standard of luxury and comfort. The city hotels typically cater to upscale travelers and business executives on expense accounts. Personalized service is stressed so much that its hotels employ an average of three persons per room.

Oberoi Hotels maintains a network of marketing professionals in sales offices in Australia, India, North Africa, Southeastern and western Asia, the U.S., and throughout Europe. The group also maintains a reciprocal marketing and reservation arrangement with Loews Representation International and Leading Hotels of the World. Oberoi strictly monitors marketing strategies to ensure the worldwide image of Oberoi Hotels is maintained and enhanced.

The company is not immune to frequent-guest promotions. It cultivates domestic consumer loyalty with its Oberoi Executive Club and offers special services to valued clients. Oberoi's domestic and international market target is identical - the affluent, qualityconscious traveler who is seeking an international standard of luxury and comfort with a high degree of personalized service. Oberoi Hotels overall enjoy a 40 -percent repeat business.

\section{Segmented Markets}

Oberoi is also well aware of the possibilities of product differentiation. Two Oberoi hotels stand side by side in Bombay. The Oberoi Towers, a 650-room hotel, aims at the general public, while the newer hotel, the 350-room Oberoi, caters to the top-of-the-market segment, mainly business travelers and dignitaries. The difference between these two hotels is like night and day. The atmosphere in the larger Towers is that of a busy, bustling inner-city property with holidaymakers, airline crews, and tourists, while the Oberoi's ambience is serene and peaceful.

\section{Economy Market}

Oberoi will be competing in a new market segment through an agreement with Accor's Novotel chain. A contrast to Oberoi's current strategy, the joint venture plans to build 20 four-star hotels in India. Oberoi is counting on Novotel's expertise with economy hotels in developing countries, while Novotel will benefit from Oberoi's knowledge of India. The hotels will average under 100 rooms, with room rates projected at US $\$ 30$ to $\$ 40$ per night. Novotel will participate in project equity and provide systems and building plans. Oberoi will manage the properties.

\section{Food Service}

Oberoi has designated a 3.5-acre site in Delhi for its flight-catering division. The unit prepares 4,000 meals a day and supplies food to ten airlines. The flight kitchen has separate sections for continental and Indian cuisine, for hot and cold 


\section{Oberoi School of Hotel Management}

Established in 1966, the Oberoi School of Hotel Management (OSHM) is the only privately run institution recognized by the International Hotel Association. Housed in the Maidens Hotel in Delhi, the school will soon relocate to a new campus a few miles from the Oberoi residence.

On-the-job training. The Oberoi policy emphasizes first-hand practical experience for the students. Much of the training program is on-the-job training. The school features a fully equipped training restaurant that can seat 60 persons at a time. Trainee appraisal is conducted by department heads at the Maidens.

Oberoi's basic curriculum is an intensive, two-year course in hotel management. Promising students go on for three years of management training at various Oberoi properties. Those interested in food service continue for another year in the kitchens at various units to complete a three-year diploma in food production.

Oberoi pays particular attention to training housekeepers, who can complete a one-year certificate course in housekeeping. Students attend OSHM for six months and then spend the next six months at various properties.

The student body is drawn from the nations where Oberoi does business, including Sri Lanka, Egypt, Nepal, Saudi Arabia, and Indonesia. Biki Oberoi personally interviews every hotel-school candidate for the maximum of 40 openings that are available each school year. (Oberoi also interviews each student midway through the program and upon graduation to determine appropriate placement.) The competition to get into the Oberoi Hotel School is intense as there are approximately 2,500 applicants annually. In one recent year, 10,000 persons applied. Just 23 were accepted. There have been 550 graduates since 1966.

The faculty members are selected from among proven professionals at Obero hotels worldwide with a rotation-selection system designed to ensure that up-todate knowledge is backed with practical experience and that the students deal with current problems. Most of the full-time faculty are OSHM graduates, ensuring continuity of the company culture. The system of rotating senior executives as teachers in the school ensures that the latest industry techniques are passed on to trainees.-C.S.D.

overseeing existing hotels and investigating the possibilities for new sites. The newest location for Oberoi hotels is the U.S.S.R. Biki says: "Here's a chance to show what we can do." What Oberoi has done is to promote his company to the Soviets by means of a top-shelf video with a sound track in Russian. Marketing on this level shows that the Oberoi company is a force to be reckoned with.

A visit to Biki's home reveals the man to be an avid art collector-an avocation that carries over to the decor of Oberoi hotels. Groomed all his life for his position, Biki carries well the mantle of one of the leading hoteliers in India. He attended the hotel management school in Lausanne, Switzerland, and now oversees his own hotel school.

One of Biki's frustrations is that his firm does not have a property in the U.S. He bought New York's Barbizon Hotel a few years ago. When he purchased it, the property comprised residential apartments. Hoping to rehabilitate the Barbizon completely, Oberoi attempted to buy out the 140 tenants. New York City's rentcontrol laws made the apartments too attractive, however, and his effort failed. Reluctantly, Oberoi sold the Barbizon. "We are still considering a prime location in the U.S.," he said, but he made it clear that just any location won't do.

\section{Motivation for Success}

Although Oberoi's hotel properties are top quality, when he is asked for the secret of his success, Biki says his employees are his biggest asset. "If we didn't have our people, we'd be nowhere," he said. "I personally spend much of my time on motivation."

Money alone is not enough to motivate employees, Biki said. Instead, motivation depends on listening and talking. "Half the battle is lost if you don't listen to people. They must be able to participate in decisions." At the same time, Biki finds it important to discuss the future with his employees. He believes people want to know whether they have a chance for promotion, or whether their performance will leave them in their current job. "If people are not told these things, they lose motivation," he said.

Training is essential to the Oberoi strategy. He looks for intelligent people who have pleasant personalities, are able to communicate, and are willing to work hard. $\mathrm{He}$ is convinced that anyone can be trained to work in a hotel if they have the proper basic skills. "If a person has good taste, is well traveled and well read, has varied interests, and likes food and drink, that person can be a hotelman with little training. My fellow hotel operators might not agree, but I think this is not a complicated business," he said. "It has become more complex, though, with financing, strategy, and the like."

Oberoi resists the trend toward ever-larger hotels. He is convinced that he cannot fulfill his promise of high service in a large hotel. "I have fought expansion tooth and nail. If you get too big, you spoil the hotel. It is better to upgrade the rooms to improve your rate." At one property Oberoi did so by adding private swimming pools.

Summing up his strategy, Oberoi said, "We don't want huge hotels. We want to be recognized as a quality hotel operator with wellknown hotels that provide something different." $\square$ 